\title{
12
}

\section{Development and Maori society: building from the centre or the edge?}

\section{Shane Jones}

The basic question in this chapter on Maori development is whether the rebuilding of Maori society should proceed from the rejuvenation of tribal membership rolls, or from other forms of organisation. The debate is a complex mixture of cultural nationalism, separating commerce from community, battling mainstream antagonism and discovering whether the trickle-down theory can overcome growing political dissatisfaction.

New Zealand has a population of approximately 3.5 million people. They are predominantly pakeha, of European extraction. The next largest group are the Maori, descendants of the original Polynesian settlers, who comprise almost 12 per cent of the total population. Their ancestors signed the Treaty of Waitangi, which was entered into between the chiefs on behalf of their tribes and the British Crown in 1840.

The Treaty is a bilingual document, having been written initially in English then translated into Maori by the Anglican missionaries. It contains three articles, each of which has been the subject of great disagreement between successive generations of Maori and the Crown. The first article ceded sovereignty to the Crown. The word 'sovereignty,' however, was not translated clearly. Rather than using the ancient Polynesian word mana, a transliteration, kawanatanga 
(kawana, from English 'governor') was favoured. The latter, a term used by the translators of the Bible to describe the status of Pontius Pilate, did not convey the concept of handing over powers of ultimate political authority.

The second article recognised Maori ownership of natural resources and guaranteed the continued authority of the chiefs. The precise extent of this authority was not however outlined. It was seen as a threat to the sovereignty of the Crown and, not surprisingly, disappeared from the political framework. The ownership by Maori of land and natural resources was soon weakened once the European settlers had increased in numbers and the Crown had a large enough military presence.

The third article accorded to Maori the rights and privileges of British subjects. This however was of limited relevance because the actual Treaty was not incorporated into the domestic law of New Zealand and was ruled as having no legal status. At the time of the signing of the Treaty, New Zealand was overwhelmingly under the control of the Maori chiefs, but as each decade passed, immigration increased and the Maori soon became a minority. As European settlers arrived and possessed the resources of the countryside and ocean through a host of means ranging from war through to legislative fiat and free transactions, the pressure grew to create a system of government which was controlled by settler society rather than colonial governors.

This was achieved with the Constitution Act 1852, which led to the creation of a legislature and the establishment of a system of government where authority for law-making was based in New Zealand as opposed to being exercised through the Queen's representative. During this period where there was a transfer of political power from the Crown to the settler-dominated legislature, the Maori chiefs continued to assert the importance of their relationship with the distant British Crown. They continually pointed to the founding document, the Treaty of Waitangi, as the protection of their rights and authority over their people and resources. Their entreaties, however, fell on deaf ears. As each decade passed they were encouraged to take the matters up with NZ governments, as they were seen as issues of domestic policy. Needless to say the tribes suffered further and within 20 years after the signing of the Treaty of 
Waitangi over 45 million acres of the country had passed from Maori ownership. The appetite for land continued unabated. Throughout the 1800s the pressure exerted on Maori to yield their resources was constant. Wars were fought, and as payment for services, the colonial soldiers received land.

As in any frontier economy the largest profits went to those who speculated on the land. The distinction between legislator and land speculator was virtually nil. To aid the land alienation process a special court, the Native Land Court, was created in the 1860s. Its purpose was to convert customary title into a form that was recognisable in terms of British-based tenure law and alienable. It was a devastating and cost-efficient way of completing the process of alienating tribal land, and by the turn of the century less than 10 per cent of the land base of New Zealand was left in Maori ownership. The Maori population sank perilously low at this time, declining to a mere 40,000. This led commentators of the day to conclude that Maori were indeed a dying race. Poor health, constantly high infant mortality rates, decrepit housing, insufficient land resources, grossly inadequate educational opportunities and a general marginalisation rendered Maori vulnerable. Despite this, however, the Maori rates of participation in both the World Wars was very high. In each war Maori made very significant contributions and were formed into distinctive organisations, the most notable being the Maori Battalion of World War II.

The socioeconomic status of Maori has continued to be a blight within New Zealand. During the 1960s and 1970s an enormous shift took place as entire rural hinterlands were emptied of their Maori populations. The growth of New Zealand manufacturing, the wool boom and a general positive performance of the economy meant there was a great need for labour within the cities. Attempts to develop Maori land-holdings were not adequate to meet the rising needs of the population. Fishing was not an option as the capital barriers were substantial, licenses were difficult to procure and the law did not recognise the existence of Maori customary fishing rights. The writing was not only 'on the wall' but within the bureaucracy as well, as government officials encouraged and facilitated the urban migration of Maori. Unfortunately the infrastructure within the cities could not cope with the arrival of such large numbers of Maori. Although 
housing was eventually made available it was often located in areas where there were no other services. The support networks of the extended family were not able to cope, and problems followed.

The vast majority of the Maori population no longer speak the language, the family structure has eroded to a point where approximately 50 per cent of Maori children are brought up in singleparent families and a larger proportion are being raised by parents or care-givers who receive welfare benefits. Subsistence on a marginal rural resource base has been overtaken by welfare dependency.

During the 1970s Maori (primarily rangatahi, young people) begun to publicise through protest action the poor socioeconomic status of Maori and they focused on the Treaty of Waitangi. The Treaty, after years of neglect and dismissal by governments became an icon for Maori aspirations. Within Maori society it had never been forgotten. For mainstream society however its status had been severely diminished. Successive generations of New Zealanders had been fed a diet, through the education system, of the 'happy go lucky Maori' and the inevitability of assimilation. The low social status of Maori and their marginal economic status was never critically analysed or understood by educators in terms of the abandonment of the Treaty of Waitangi.

During the 1970s and 1980s, as the Treaty became more the object of political activism and social commentary, the political parties slowly adopted resolutions requiring that the Treaty be recognised and grievances concerning the historical loss of tribal resources be investigated and settled. The judicial system could not satisfactorily respond to the Treaty as it did not have legal status. The route forward was inexorably political. It was an extraordinary development that a seemingly obscure, colonial artifice, a 'toothless' document, should influence the economic and political agenda of governments in the final years of the twentieth century.

In 1975 the Labour government established a special Treaty of Waitangi Tribunal to hear claims from Maori as to how the principles of the Treaty had been violated through legislative action or policy. It was given powers of recommendation but could only consider claims arising from actions after 1975. In 1985 when the same political party became government again, after many years in opposition, it went further and enabled the Tribunal to hear grievances stemming from the time that the actual treaty was signed. This effectively served up the entire colonial history of New Zealand for inspection at the end of the twentieth century. 
At the time these changes were taking place, the New Zealand system of government and the economy went through a rapid series of reforms. Vast areas of the government were restructured into commercial and non-commercial enterprises. The former became state-owned enterprises under a statute known as the State Owned Enterprises Act. Telecommunications, forests, hotels, railways, shipping companies, energy supply companies and a host of other operations were either corporatised or sold outright. Virtually every sector of the economy was restructured. Unemployment grew markedly, and Maori were the principal casualties.

In a macroeconomic sense New Zealand has undertaken a series of reforms that has captured the attention of international economic policymakers. It is quite incongruous that this economic liberalisation has taken place at the same time as the historical grievances of Maori have been given legislative space to grow. In terms of socioeconomic status, Maori fortunes have plummeted as the reforms have set in. Whether a process focused on historical events can address contemporary socioeconomic problems for Maori remains to be seen. The publicity surrounding the historical Maori claims has grown enormously. The dislocation from the structural adjustment programs implemented by recent governments has caused anger and resentment towards Maori and their claims under the Treaty of Waitangi, the implication being that the Maori are enjoying a separate and privileged treatment.

\section{History: retribution or recovery?}

It is interesting to note that as the historical grievances have been examined by the Waitangi Tribunal, Maori have endeavoured to weave together several development strategies. First they have sought to affirm the primacy of Maori as tangata whenua, the original people, the indigenes. To do this it has been necessary to draw on oral testimony which reinforces pre-Christian beliefs and stories about the creation of the world, the order between people, environment and the universe. This has given greater exposure to traditional Maori cosmology and served as an introduction for younger Maori of their ancestors and their kaupapa, foundation beliefs. It serves to boost the mana, the sense of power, status and prestige, inherited from the ancestors and the gods.

In terms of development this process of affirmation is likened to a rite of passage, giving development strategies a root against which colonialism can be measured. Not suprisingly it also easily becomes an 
ideological tool. For the more politically inclined it is wielded as evidence of the degrading and destructive legacy of British imperialism. Maori identity must be refashioned or rearranged to give absolute primacy to the pre-colonial ideas and concepts of belonging, place and achievement. Given that these are impossible to know, there is an broad scope for interpretation.

For those who wish to see the growth of the market economy and its stress on personal responsibility, the importance of being tangata whenua is principally about property. After all, how can one enjoy primacy unless there is a set of rights outlining that which you hold primacy over, and that which ought to be kept well beyond the grasp of collective power? In this view, the magico-spiritual notions are personal beliefs and tolerable providing they do not inhibit the growth, exchange or trade in property.

Whether there is virtue in either of these two views cannot be settled here. Rather it is to illustrate that the development debate is saddled with having to resolve the deep feelings of sadness and resentment that Maori have been denied their historical place. Their history over the past 150 years has been the victim of a conspiracy of silence. Through inattention and an unwillingness to depict the causes and impacts of historical resource loss accurately there is now a well of scepticism.

The hearing of evidence as to how the ancestors were militarily overcome, forced to yield their resources and then reduced to constant poverty, is both a relief and a burden. For many it is an overdue recognition of what actually took place as New Zealand pakeha sought to make their place. The moral force of the Treaty of Waitangi was overridden; the Maori were not the authors of their own demise. When the Crown acknowledges that indeed much of what took place was in direct contravention of the Treaty, it is often regarded as vindicating the stance taken by the ancestors and affirms that they were not inferior. The mana of the ancestors remains intact. Having achieved that, it is appropriate to move from grievance mode and into development mode.

Such a process, however, becomes a burden if the current generations of pakeha are held responsible for every crime or historical error towards the Maori. With the restoration of mana the spirit of retribution creeps in. In a quantitative sense it is neither possible nor necessarily desirable to force current generations to recompense Maori for historical wrongs fully. Obviously it is unfair that the Crown 
allowed the Treaty to be violated and that Maori have lost the majority of their resources. The notion of fairness however is double-edged. Current generations of pakeha are adamant that they should not bear the brunt of the costs of colonialism.

The burden becomes evident when development is seen as synonymous with 'selling out' one's heritage. It is easier for many to maintain a sense of grievance against the Crown because this conveys an air of righteousness. It is also far more comfortable than taking responsibility for trying to move on from a heavy chapter of history, especially when any move may be condemned by future generations and will most certainly be criticised by a sizeable chunk of the current generation. Setting out to honour one's ancestors and salvaging their aspirations through retrieving the Treaty is often only a short distance from descending into a spiral of victim mentality.

\section{From the centre or the edge?}

Rights are social constructions and must be accompanied by countervailing duties. Their nature and character is altered as the circumstances impacting on the holders and the resource change. The original rationale of entitlement may remain but the extent to which that rationale can be satisfied is not set in stone. Rather it flows, and it is inevitably in conflict with expectations or the needs of the various groups that may have interests in the entitlement.

Given the primacy accorded to culture and its central importance in defining the modern identity of Maori, it is not surprising that there has been a growing interest in revitalising the identity and the operational capacity of the tribes. These are sociopolitical forms of organisation that were recorded as being in existence at the time of the Treaty of Waitangi. It is asserted that the rights that were lost in the process of colonisation were vested in the tribal collectivities. The losses may have been suffered by individuals and their personal circumstances may have been blighted, but the repository of the rights is the collectivity. It is asserted that by doing this, the integrity of the culture is safeguarded and the identity of the individual is assured, along with their tribal patrimony. In practice this means that the capital to be transferred by the Crown, as a consequence of the historical claims being satisfactorily settled, is to be vested in corporate bodies representing the tribal membership. Given that one can never renounce one's tribal membership it is envisaged that this type of arrangement will sustain the existence of the tribe. 
The challenge, however, arises when theory meets reality. The Maori population is overwhelmingly urbanised. It is by no means clear that a majority of Maori are regularly involved in tribal affairs. The tribes are rooted in certain territories, virtually all of which are rural, with an occasional urban presence. If there happens to be a city or large town within their boundaries, it is difficult to maintain contact with the full membership of the group.

The importance of the settlement of historical grievances is bound up with the affirmation of mana and the transfer of capital. Development cannot be sustainable if mana is not left intact. It represents the link with the past, both ancestral and divine, the roots of identity, as reflected in the well-known saying, He purapura i ruia mai $i$ Rangiatea, $e$ kore au e ngaro-A shoot planted in Rangiatea, I will not be lost.

Capital is a means to an end. As we proceed with the historical grievance settlement process, it is apparent that the end has more to do with sustaining the ancestral legacy, to ensure that future generations of Maori are well-adjusted in their culture. Increasingly added to this, is the notion of being competitive in the economy. To this end the debate about resource endowments looms large. The capacity of these endowments, however, in actually changing the material well-being of Maori depends on the quality of management. As Maori emerge from a prolonged period of poor education, suspicion of mainstream institutions, in particular the justice system, and poor socioeconomic status, the management of the capital flowing from these tribal settlements is a difficult issue.

In addition, the national census statistics show that 25 per cent of the population of Maori descent do not know their tribal affiliation. This is perhaps not surprising given the historical pattern of resource loss and the marginal position which tribes have had in terms of economic activity. Very few have been able to offer material assistance to their members. However, within the development model, flowing from the settlement of historical grievances, tribes are given an important role. Not only are they seen as being the body to receive assets but also the body to distribute the benefits, and this is a problem if significant numbers of the potentially eligible group are not known or have lost contact with their tribal kin and the administration.

This problem is currently before the courts in New Zealand as organisations formed to advance the interests of Maori based in the cities, are challenging the exclusive authority of the tribal bodies to deliver resources and fulfil development programs. The urban bodies 
wish to be included in the list of organisations eligible to receive assistance from the Treaty of Waitangi Fisheries Commission-a body formed to hold, administer and distribute resources to Maori from the multi-million dollar fisheries settlement completed with the Crown in 1992.

The urban organisations do not doubt the existence of Maori tribal bodies or their importance. They are, however, adamant that the Maori population is dynamic and institutions need to change to service the needs of Maori. In their view the needs of city-based Maori will not be met by traditional tribal bodies. They view the settlement of historical grievances as being primarily to compensate individual Maori and to assist them break out of dependency. To do this there need to be programs that are tailored to meet their needs, based on a very good understanding of their actual situation and the capacity to work closely with them.

A further view is expressed by those who do not favour the allocation of resources to tribal bodies because of human capital constraints. In their view the transfer of resources to Maori from the historical grievance process should be dedicated to building up large corporations with growing capital bases. The funds should be dedicated to meeting growth targets, maintaining technology advances and investment in people through a dividend policy that sees them engaging in further education and training. This is regarded as a centrist approach and is criticised as undermining the cultural identity of Maori. By not treating the tribe as the primary body for the vesting of resources, it is regarded as a 'sell-out'. The Waitangi Tribunal has crystalised its thinking into a development model known as the tribal endowment thesis. It promotes the notion that all tribes require a critical mass of resources, a resource base that ensures all its members are able to learn tribal history and receive assistance for education and business development. An estate that they and their descendants can call their turangawaewae, a place to stand and celebrate their roots, a home away from the cities, and a place where each generation renews its ties with the past.

For fear of losing readers with too much detail it is important that several points are stressed here. Cultural politics cannot be underestimated. A particular model may make sense in a strict corporate, commercial sense. If, however, it is seen as weakening the capacity of the tribes to actually take possession of resources and engage in the development of those resources, it is likely that conflict 
will ensue. By and large the tribes are seen as being the legitimate bodies to advance the interests of Maori in terms of land-based historical settlements. In a linear sense they are the inheritors of the rights and resources denied to their forefathers. They are and will be handicapped for some time to come, however, as there are simply not enough skilled people from within their own ranks to fill the management responsibilities. This is only a temporary problem and will change as young Maori graduate, gain experience and take a place in the development of their own assets. Given the limited contact that the corporate world has had with Maori it will take a long time before the two worlds discover how to make their way together.

By and large the resources being returned to Maori lock them into the operations of the economy. The fisheries grievance was settled by assigning cash, share and fishing property rights (individual transferable quota) to Maori. The aspiration of the Maori leadership is for assets that generate immediate commercial returns, that can then be made available to the population in the form of dividend payments. The current leaders are very suspicious of the concept of investing to create work, although it is apparent that the greatest problem in Maori communities is unemployment. The model of the subsistence economy is not applicable to Maori today. The welfare dependency syndrome is relevant. Although the pressure is great to alleviate these problems, there are no major initiatives emerging from the historical grievance process to respond specifically to welfare dependency. By and large this is seen as a matter of personal responsibility and government action, and Maori urban authorities receive resources from the government to do this type of work. The tribal administrators, however, assert that if government cannot fix the problem, the tribal bodies will have greater difficulties, with their limited resources. Unless such problems are resolved, the amassing of assets and wealth under the name of tribal development may end up being of dubious benefit.

The distribution of resources is a question that Maori have only begun to address in the context of the historical grievance process. It is most certainly a critical issue. Unless the structure of Maori society is changed there will be no significant developments, notwithstanding the examination and laying bare the body of nineteenth century colonialism. Effecting a change to the structure of a society requires major investments in education, Maori are perhaps the most vulnerable in this regard. 


\section{Sustainability: fiat or ethic?}

The Resource Management Act 1991, is the principal planning and management statute in New Zealand. Its purpose is the sustainable management of natural resources. More recently the Fisheries Act 1996, has been enacted with a similar provision. In each of these acts the notion of 'sustainability' is directed primarily at the natural environment. Social considerations are not given a prominent position, although economic issues of efficiency, and compliance costs of regulation, are an important consideration.

These statutes do, however, give status to kaitiakitanga, a term that is interpreted by the legislation as meaning 'the exercise of guardianship, in relation to a resource, including the ethic of stewardship based on the nature of the resource itself'. Kaitiakitanga derives from the word tiaki, which means to foster, to preserve and to protect. The prefix kai with the verb indicates the agent of the act. A kaitiaki is a guardian, conservator, foster parent, or protector. The suffix tanga added to the noun means guardianship, fostering, conservation and protection. In relation to environmental management kaitiakitanga is regarded as an ethic. It does not involve Maori having authority over natural resources independent of the statutory regime, but the incorporation of Maori terminology into the statutory lexicon has been seen as a triumph for Maori environmental values. It allows Maori to require formal environmental decision-makers to take into account a wider range of interests when natural resource decisions are made.

The pursuit of sustainability through improved environmental decision-making represents an interesting situation for Maori. Sustainability is associated with the imposition of limits to growth. The problem arises when these limits are measured and then imposed on Maori developments. More often than not, Maori communities will stress that they have a better approach to the protection of the environment than pakeha. This is often met with disdain by the members of the environmental movement, who quickly point out that large numbers of birds were wiped out by Maori prior to the arrival of pakeha. The application of the principles of sustainability is quickly overtaken by a political debate as to whether Maori resource-use decisions should be subject to legislative provisions. There have been cases where Maori have sought to mill native timber, which is a particularly scarce resource and an important habitat. Earlier generations of pioneers milled the vast majority of the native forests. 
Current Maori landowners assert that they should be permitted to use their resources to improve the parlous socioeconomic status of their communities. In their view it is an equity issue. Why should they bear the full costs of retaining the final vestiges of the flora and fauna? There has been a range of formal responses, including the establishment of a fund to compensate forest owners. The level of milling has dropped off considerably. The conundrum, however, remains. In order for Maori to pursue the development of such resources they must run the gauntlet of public opprobrium. If the Crown agrees to compensate them for lost opportunity they are likely to be branded as carpetbaggers, but if they proceed to mill the resources, they are attacked as brown capitalists using the ethic of sustainability to suit their personal circumstances.

The conservation estate, those resources administered by the Department of Conservation under the Conservation Act, 1987, is the new theatre of conflict. This is where political debates between the environmentalists, tribes, tourism operators and the Crown are taking place. As the historical claims process gathers pace, the pressure to open up the conservation estate and transfer parts of it into Maori ownership grows. The majority of environmentalists view the estate as sacrosanct. For the Crown, however, it is of mixed importance, as not all of it is of high conservation value.

For Maori it has a range of values. It is a source of valuable material for arts and crafts. It also the location of many of important sites that represent identity, and the resting place of the ancestors. In addition, it is of economic value as a location for tourism. Such agendas for development are seen as a threat to sustainability. The environmentalists frequently criticise the Maori conservation agenda as being primarily driven by commercial motives. The tribes in response insist that they have been fine stewards of their resources and the public need not have any concerns. The debate about the conservation estate take places in many cases because there are precious few other blocks of economic resource which can be used to recompense the tribes for historical loss. The other resources such as the exotic forestry plantations developed by the Crown over the twentieth century have been sold as a part of the restructuring of the national economy. The former farms developed by successive governments have been corporatised, and are administered as state owned enterprises. This incenses the environmental constituency, who see the conservation estate as having to bear the freight of Maori development aspirations. 
This is a reasonable fear given the pressure on Maori leaders to create employment for their people, but the employment potential of the conservation estate is very limited. In fact many of the resources likely to be included in the Treaty of Waitangi settlements, including the fisheries settlement, are not capable of generating great numbers of jobs. The pressure on the conservation estate to yield employment opportunities is likely to force owners to consider projects that are threatening to environmentalists. Redressing historical resource loss may result in asset transfers; such transfers of resources, however, will require ongoing sustainable management. There will not be a separate regime for the tribes to manage their resources as they see fit.

Decisions will be made and bound by the standards contained in the Resource Management Act and associated planning schemes.

As Maori adopt more of a corporate approach to the organisation and development of their resources, the costs of sustainability will begin to bite. This has already begun to take place within the fishing industry. Maori shareholders are increasingly uneasy about the depletion of fish stocks. Their concerns, however, are not easily translated into management action. Competitors are not obliged to follow suit and desist from fishing in certain areas or for certain species. The fishing techniques are capital intensive, the markets are fickle and the margins are tight for the owners of fishing assets. Inevitably the fishing activities of large companies are a threat to customary and non-commercial Maori fishing. This is unavoidable as the fisheries cannot cope with the expectations of the recreational sector, as well as those of commercial investors. The resource, like all fisheries, is continuing to decline. Maori custom might advise a reduction of effort but the commercial costs may require an intensification of effort. In this sense the injunction of sustainability has an impact on Maori in an orthodox, commercial, sense as well as a customary sense. This is a consequence of attempting to redress historical claims by transferring assets which require participation in industries which have been viewed with scepticism by Maori in the past. The commercialisation of customary resources has been the outcome of the developments flowing from the Treaty of Waitangi settlement process, bringing about the accelerated involvement of Maori in the economy after many years of marginal participation. Maori leadership is opposed to a development process that does not have Maori at heart, and eventually driving it-but the process is international and highly competitive. 


\section{Conclusion}

Maori development is framed by the terms of the Treaty of Waitangi reconciliation process. It is the process where there is a transfer of resources, ostensibly to settle the historical wrongdoing of colonial governments, but also to improve the resource base of Maori and thus strengthen their capacity to participate in the economy. The task is premised on the notion that Maori had rights that were in existence prior to the arrival of the British. Those rights were not respected by the Crown after the Treaty was signed. The task now is to give economic force to those rights through the transfer of resources, and greater recognition of the importance of Maori language and culture.

Separate political development is not on the political agenda. While there is support for the settlement of historical grievances, and an economic transfer of resources is countenanced, the purpose is to integrate Maori further into the mainstream of the economy. The sentiments of nationalism are given expression through language and culture rather than through the creation of institutions of selfgovernment. The desired result appears to be economic prowess and cultural cohesiveness. Political development is mediated through a set of regular parliamentary elections where Maori are integrated into mainstream political parties.

Culture and language is being restored after long periods of neglect. Social change has altered the character of Maori identity and now poses questions that are more akin to those of inner urban areas in the United Kingdom or the United States, than those associated with traditional societies reeling from the impact of outside culture. This impact has taken place as Maori have declined to a low status in their own country. The recovery of status is emerging through the settling of historical claims - a process that requires considerable political skill and a capacity to compromise.

The agenda for development debates within Maori society is rooted in the political process. It rests uneasily on assumptions about the effectiveness of market-led economic reforms as a basis for improving the position of Maori in the labour market, tribal enterprise development and the distribution of resources within Maori society. Discussions on how to address welfare dependency echo with voices and ideas that come directly from the United States. At the same time the relentless push for Maori identity through the promotion of the 
Treaty of Waitangi, indigenous culture (at a time when MTV and CNN beam into virtually every house), and language retention, reflect a need for adaptation in the models for economic development, to capture the full range of Maori ambitions. 